\title{
Splenic cyst hydatid: A case report
}

\author{
Splenik kist hidatik: Bir olgu sunumu
}

Mustafa Sit*, Gülali Aktaş, Aytekin Alcelik, Edip Erdal Yılmaz

Department of Internal Medicine, Medical Faculty, Abant İzet Baysal University Hospital, Bolu, Turkey

\begin{tabular}{l}
\hline ARTICLE INFO \\
\hline \begin{tabular}{ll} 
Article History \\
Received & $31 / 01 / 2012$ \\
Accepted & $02 / 04 / 2012$ \\
\hline
\end{tabular} \\
\hline
\end{tabular}

\section{* Correspondence to:}

Mustafa Sit

Abant İzzet Baysal University Hospital, Department of Internal Medicine,

Bolu, Turkey

e-mail: drmustafasit@yahoo.com.tr

\section{Keywords:}

Hydatid cyst

Spleen

Splenectomy

Autotransplantation

Abdominal pain

Splenic functions

\section{ABSTRACT}

Hydatid cyst is the most common cause of parasitic cysts in spleen. Hydatid cysts may be isolated in spleen or as a part of disseminated echinoccosis. We report here a case of splenic hydatid cyst which we treated with splenectomy and autotransplantation. A seventeen year old female admitted to hospital complaining dull abdominal pain. Patient was diagnosed with primary splenic cyst hydatic and we performed splenectomy and autotransplantation. In conclusion, we recommend that cystic lesions of the spleen should be examined for hydatid cyst. Splenectomy and autotransplantation is useful for both treatment and for preservation of splenic functions.

J. Exp. Clin. Med., 2012; 29:239-241

\section{ÖZET}

Kist hidatik dalakta en sık görülen parazitik kist sebebidir. Dalakta izole olabilecekleri gibi dissemine ekinokokkozisin bir parçası olarak da bulunabilirler. Bu yazıda splenektomi ve ototransplantasyonla tedavi ettiğimiz bir splenik kist hidatik vakasını sunmaktayız. On yedi yaşında bayan hasta hastanemize karın ağrısı şikayetiyle başvurdu. Hastaya primer dalak kist hidatiği tanısı konularak splenektomi ve ototransplantasyon yapıldı. Sonuç olarak dalaktaki kistik lezyonların kist hidatik açısından değerlendirilmesini öneriyoruz. Splenektomi ve ototransplantasyon hem tedavide hem de dalak fonksiyonlarının korunmasinda etkindir.

J. Exp. Clin. Med., 2012; 29:239-241

\section{Anahtar Kelimeler: \\ Hidatik kist \\ Dalak \\ Splenektomi \\ Ototransplantasyon \\ Karın ağrısı \\ Dalak fonksiyonları}

\section{Introduction}

Cystic lesions of the spleen are classified as primary or secondary depending upon the underlying etiology. Primary cysts are subdivided into parasitic and non-parasitic. The parasitic cysts occuring after infection with Echinococcus granulosus are the most common form and the most frequent etiologic agent (McManus et al., 2003). Hydatid cyst is the most common cause of parasytic cysts in spleen. The cysts grow as slow as 1-2 cm per year (Kireşi et al., 2003; Singh et al., 2003). The disease is still endemic in many countries. More than $90 \%$ of hydatid cysts occur in the liver and lungs (Vasilescu et al., 2010). Spleen is the third most common site for echinococcosis after liver and lungs (Malik et al., 2011).
Hydatid cysts may be isolated in spleen or as a part of disseminated echinoccosis (Malik et al., 2011). Primary splenic hydatidosis is characterized with involvement of only spleen not the other organ systems. Primary splenic involvement is an uncommon manifestation of hydatid disease and should be suspected upon detection of any splenic cyst in an endemic area (Hamamci et al., 2004). Human echinococcosis causes significant health problems with reasonably high morbidity and wastage of resources and is usually the most frequent parasitic cyst of the spleen (Durgun et al., 2003; Sharif et al., 2009).

Hydatid cysts of the spleen occur at all ages and in both sexes and they may be detected incidentally or may present 
with nonspecific symptoms and signs (Amman and Eckert, 1996; Safioleas et al., 1997). Rare complications of the cysts are infection, fistulization to adjacent organs and rupture (Malik et al., 2011). Serology, abdominal ultrasound (US) and computed tomography are usefull to make diagnosis. Treatment varies from spleen preservation to splenectomy (Amman and Eckert, 1996; Kireşi et al., 2003). We report here a case of splenic hydatid cyst which we treated with splenectomy and autotransplantation.

\section{Case}

A seventeen year old female admitted to hospital complaining of dull abdomial pain. Pain is localized to upper left quadrant of the abdomen. The pain has been continued for last two years but it intensified in last 3 months. Physical examination revealed tenderness on palpation in the upper left quadrant. Spleen was palpated under the left costal margin. Biochemical and hematological laboratory tests were in normal range. Abdominal ultrasound and computed tomography revealed splenomegaly and splenic cystic lesion (Fig. 1).
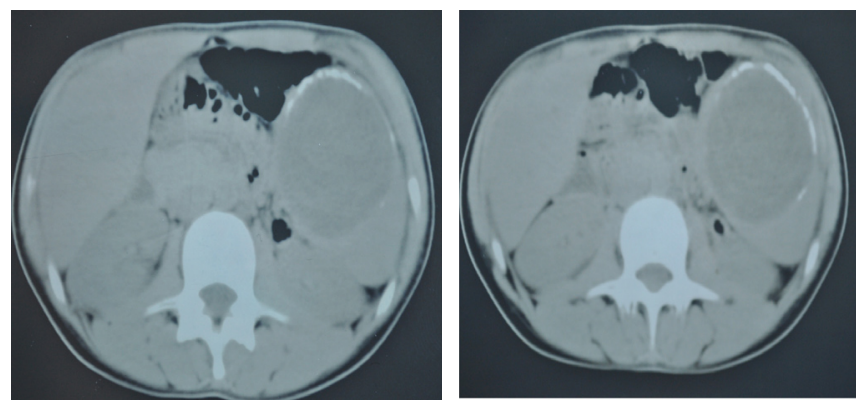

Fig. 1. Computed tomography scan images of the splenic cystic lesion

There were no other lesions on imaging studies. An indirect hemaglutination test for echinococcus antigen was positive. Patient was diagnosed with primary splenic cyst hydatic and she has been prescribed albendazole $400 \mathrm{mg}$ twice a day a week before the operation. She also has been vaccinated for pneumococcus in preoperation period. We performed splenectomy and autotransplantation.

\section{Discussion}

Splenic hydatid cysts are only $0.5-8 \%$ of all hydatid cysts (Amr et al., 1994; Amman and Eckert, 1996). Nearly twothirds of splenic cystic lesions are due to hydatidosis (Kune and Morris, 1990; Amr et al., 1994; Wani et al., 2005). Splenic hydatid cysts are usually solitary (Shukla et al., 1991) but there are also cases presented with multiple cysts. There may be hydatid cysts in other parts of the body in 30\% of splenic hydatidosis (Safioleas et al., 1997; Ozdogan et al., 2001; Durgun et al., 2003). In our case there was only a solitary splenic cyst.

There are several ways for Echinococcus granulosus to reach the spleen: 1-through blood stream, 2-through lymphatics (Amman and Eckert, 1996), 3-reflux from portal vein when intraabdominal pressure increases (Singh et al., 2003). About $30 \%$ of the splenic cysts are silent (Malik et al., 2011). The most common sign is splenomegaly (Kireşi et al., 2003; Singh et al., 2003). Symptoms of splenic hydatid cysts are non specific (Alfageme et al., 1994), such as, abdominal lump, abdominal ache, dyspepsia, constipation due to pressure on colon, and dyspnea due to pushing up of the left diaphragm (Malik et al., 2011). The patient was complaining for abdominal dull pain for 2 years in our case.

Hydatidosis may be associated with complications such as infection of the cyst, rupture of the cyst into the peritoneal cavity, fistula formation into hollow viscera like colon or stomach (Bitton et al., 1992), bronchopleural fistula, sympathetic pleural effusion, calcification (Uriarte et al., 1991), hypersplenism, and severe utricaria (Lewall and McCorkell, 1986) in some patients. There was no complication of splenic cyst hydatid in our patient.

The blood counts are usually normal. Eosinophilia is the most common laboratory finding (Safioleas et al., 1997). Serum immunoelectrophoresis is a reliable serological test, with a sensitivity of approximately $90 \%$ and it stays positive for up to 12 months after the infection has been eradicated. Indirect hemagglutination test has a lower sensitivity of $85 \%$ but remains positive for several years (Amman and Eckert, 1996). Other tests available are complement fixation, enzyme linked immunosorbent assay (ELISA), western blot analysis and Casoni (Bitton et al., 1992) skin tests. In our case indirect hemagglutination test was positive but hemogram and biochemical tests were normal.

Soft tissue shadowing with or without calcification in left upper quadrant of the abdomen, elevation or displacement of left hemidiaphragm are x-ray signs of the splenic cysts. US and CT scan are reliable imaging tools for diagnosis. Unfortunately images in US and CT are not specific to hydatid cysts because other cystic lesions of spleen, such as abscess, hematoma, epidermoid cyst, pseudocyst or neoplasms may present with similar findings (Durgun et al., 2003). Abdominal ultrasound and computed tomography scan revealed splenic solitary cyst in the present case. Surgery is the basic treatment choice. Splenectomy is easy, rapid and effective in management of hydatid cyst. Albendazole, an anti-parasitic agent, is usefull to sterilize the cyst, to reduce the risk of anaphylaxis, to decrease the tension in the cyst wall and to reduce the postoperative recurrence rate (Kune and Morris, 1990). Hypertonic saline or $0.5 \%$ silver nitrate injection into cyst in operation may help to kill the daughter cysts, so the risk of spread and anaphylactic reaction reduces (Kune and Morris, 1990). We initiated a treatment with $2 \times 400 \mathrm{mg}$ Albendazole before operation.

Conservative surgery like partial splenectomy, cyst enucleation, deroofing of the cyst with omentoplasty or external drainage of the cyst have been done in some cases (Lewall and McCorkell, 1986; Safioleas et al., 1997; Ozdogan et al., 2001). Splenic autotransplantation should be another choice for preserving splenic functions (Karagulle et al., 2007). In this technique, viable small parts of spleen tissue left in the abdomen; especially into an omentum pouch (Timens and Leemans, 1992). Benefits of autotransplantation have been reported previously in literature (Fashing and Cooney, 1980; Patel et al., 1986; Traub et al., 1987). According to the data in literature, we treated our patient with splenectomy and autotransplantation.

In conclusion, we recommend that cystic lesions of the spleen should be examined for hydatid cyst. Splenectomy and autotransplantation is useful for both treatment and for preservation of splenic functions. 


\section{REFERENCES}

Ajaz Malik, A., ul Bari, S., Younis, M., Wani, K.A., Rather, A.A., 2011. Primary splenic hydatidosis Indian J. Gastroenterol. 30, $175-177$.

Alfageme, I., Martin, M., Hernandez, J., Huertas, C., 1994. Rupture of a long-standing splenic hydatid cyst into the bronchial tree. Clin. Infect. Dis. 19, 992-994.

Amman, R.W., Eckert, J., 1996. Echinococcus. Gastroenterol. Clin. N. 25, 655-689.

Amr, S.S., Amr, Z.S., Jitawi, S., Annab, H., 1994. Hydatidosis in Jordan: An epidemiological study of 306 cases. Ann. Trop. Med. Parasit. 88, 623-627.

Bitton, M., Kleiner-Baumgarten, A., Peiser, J., Barki, Y., Sukenik, S., 1992. Anaphylactic shock after traumatic rupture of a splenic echinococcal cyst. Harefuah. 122, 226-228.

Durgun, V., Kapan, S., Kapan, M., Karabiçak, I., Aydogan, F., Goksoy, E., 2003. Primary splenic hydatidosis. Digest. Surg. $20,38-41$.

Fashing, M.C., Cooney, D.R., 1980. Reimmunization and splenic autotransplantation: A long-term study of immunologic response and survival following pneumococcal challenge. J. Surg. Res. 28, 449-459.

Karagulle, E., Hoscoskun, Z., Kutlu, A.K., Kaya, M., Baydar, S., 2007. The effectiveness of splenic autotransplantation: An experimental study. Ulus. Travma Acil Cer. 13, 13-19.

Hamamci, E.O., Besim, H., Korkmaz, A., 2004. Unusual locations of hydatid disease and surgical approach. ANZ J. Surg. 74, $356-360$.

Kireşi, D.A., Karabacakoğlu, A., Odev, K., Karaköse, S., 2003. Uncommon locations of hydatid cysts. Acta Radiol. 44, 622-636.

Kune, G.A., Morris, D.L., 1990. Hydatid disease. In: Schwartz, S.I., Ellis, H., editors. Maingots abdominal operations. London: Appleton and Lange. 1225-1240.

Lewall, D.B., McCorkell, S.J., 1986. Rupture of echinococcal cysts: Diagnosis, classification, and clinical implications. AJR Am. J. Roentgenol. $146,391-394$.

McManus, D.P., Zhang, W., Li, J., Bartley, P.B., 2003. Echinococcosis. Lancet. 362, 1295-1304.

Ozdogan, M., Baykal, A., Keksek, M., Yorgancy, K., Hamaloglu, E., Sayek, I., 2001. Hydatid cyst of the spleen: Treatment options. Int. Surg. $86,122-126$.

Patel, J.M., Williams, J.S., Naim, J.O., Hinshaw, J.R., 1986. The effect of site and technique of splenic tissue reimplantation on pneumococcal clearance from the blood. J. Pediatr. Surg. 21, 877-880.

Safioleas, M., Misiakos, E., Manti, C., 1997. Surgical treatment for splenic hydatidosis. World J. Surg. 21, 374-377.

Sharif, M.A., Mahmood, A., Murtaza, B., Malik, I.B., Khan, A., Asghar, Z., Arif, A., 2009. Primary perisplenic hydatid cyst. JCPSP-J. Coll. Physici 19, 380-382.

Shukla, R.A., Hathia, W.P., Dadhagara, K.M., 1991. Hydatid disease in Saurashtra study of 210 cases. In: Saksena, D.S., Jhawar, D.K., Purohit, A., editors. Surgery in the Tropics. New Delhi: Macmillan. 450-460.

Singh, H., Arora, S., 2003. Primary hydatid cyst of the spleen. Med. J. Armed. Forces India. 59, 169-170.

Timens, W., Leemans, R., 1992. Splenic autotranspiantation and the immune system. Ann. Surg. 215, 256-260.

Traub, A., Giebink, G.S., Smith, C., Kuni, C.C., Brekke, M.L., Edlund, D., Perry, J.F., 1987. Splenic reticulo-endothelial function after splenectomy, spleen repair and spleen autotransplantation. New Engl. J. Med. 317, 1559-1564.

Uriarte, C., Pomares, N., Martin, M., Conde, A., Alonso, N., Bueno, M.G., 1991. Splenic hydatidosis. Am. J. Trop. Med. Hyg. 44, $420-423$.

Vasilescu, C., Tudor, S., Popa, M., Tiron, A., Lupescu, I., 2010. Robotic partial splenectomy for hydatid cyst of the spleen. Langenbeck Arch. Surg. 395, 1169-1174.

Wani, R.A., Malik, A.A., Chowdri, N.A., Wani, K.A., Naqash, S.H., 2005. Primary extrahepatic abdominal hydatidosis. Int. J. Surg. 3, 125127. 